\title{
Attitude on intention to use e-government in Indonesia
}

\author{
Dedy Afrizal, Muslimin Wallang \\ Ghazali Shafie Graduate School of Government, Universiti Utara Malaysia, Kedah, Malaysia
}

\begin{tabular}{l} 
Article Info \\
\hline Article history: \\
Received Dec 29, 2020 \\
Revised Mar 2, 2021 \\
Accepted Mar 14, 2021 \\
\hline
\end{tabular}

\section{Keywords:}

Attitude

E-government

Intention to use

Technology acceptance

UTAUT model

\begin{abstract}
The application of information and communication technologies in Indonesia continues to be developed as the government becomes more serious in improving services to its citizen. However, there are still some obstacles to using the service. The purpose of this paper to present a framework improving e-government services to its citizen. The paper opted for using a comprehensive review of the unified theory of acceptance and use of technology (UTAUT). This paper offers ideas to see intention to the community in using e-government, by using the modified UTAUT model where the main construct performance expectancy (PE), effort expectancy (EE), social influence (SI), facilitating conditions (FC) is an important factor. Moderators such as gender, age, experience and voluntariness of use were excluded and using attitude as a mediator. The findings showed that UTAUT's construct such as performance expectancy, effort expectancy, social influence, facilitating conditions is an important factor appropriate for seeing intention to citizen in using e-government and 9 hypotheses offered in the model are believed to get new findings in the future and increase the development of the UTAUT model and be able to provide concept ideas that are made in seeing the intentions of e-government users.
\end{abstract}

This is an open access article under the CC BY-SA license.

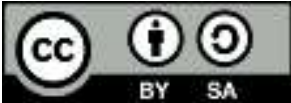

\section{Corresponding Author:}

Dedy Afrizal

Ghazali Shafie Graduate School of Government

Universiti Utara Malaysia

Sintok, Kedah, 06010, Malaysia

Email: dedyafrizal26@gmail.com

\section{INTRODUCTION}

Utilization of information technology has been an interesting discussion in the world [1,2]. These also applies to e-government aspects [3]. The use of information technology is not only centered on the government as an information system provider, but the intention to use (ITU) technology in e-government services is also interesting to discuss $[4,5]$. In reality, electronic government (e-government) services in some countries have not been implemented well [6]. The results of previous researches says that the intention of the user is the main determinant in the use of technology [7]

The Indonesian government has used information technology in its services $[8,9]$. That is the responsibility in providing the best service for the citizen [10,11]. Problems related to e-government in Indonesia are often found in local governments [12]. In addition, e-government usage conditions in Indonesia are described according to the results of the e-government development index (EGDI) in 2018 has been ranked 107 in the number 0.5258 EGDI. The ranking looks far behind those of neighbouring countries such as Singapore ranked 7, Malaysia 48, Brunei Darusalam 59 and Thailand 73 [13].

An obstacle of e-government in Indonesia that is, it depends more on incomplete technology, lack of preparation among residents, lack of human capital and an atmosphere that does not encourage the use of egovernment services [14]. Many Indonesian citizens assume that e-government is only concerned with 
operating a website [15]. The mistake of seeing e-government as a whole is one of the reasons that egovernment's implementation has not been optimized [16]. Based on the description of this phenomenon, it is important to perform a research concerning the intention of citizens in using e-government services in Indonesia.

\section{RESEARCH METHOD}

The author conducts a comprehensive review of the UTAUT construct, namely, performance expectancy, effort expectancy, social influence and facilitating condition, and attitude as an additional construction on intention to use of technology. The comprehensive review identify, as far as possible, all studies that meet a set of criteria and provide a more in-depth analysis of the research on the subject.

\section{RESULTS AND DISCUSSION}

\subsection{E-government}

Early in the 20th century, e-government played a role in revolutionizing economy in the world, by promoting an effective and efficient service process $[17,18]$. E-government is the process of delivering public services online to citizens by using ICT tools that involves government, society and business [8]. E-government uses ICT efficiently and effectively in providing services to 1) government-to-government (G2G) shares data and exchanges electronically between government actors in the national, regional and local scope, 2) government to business (G2B) electronic transaction activities that provide business services such as the purchase of goods and services, payment and sales and other business activities using the online method, and 3) government to citizens (G2C) activities of providing public services from the government to citizens using an online system $[19,20]$.

In view of citizens' welfare, a large number of policies and schemes are initiated by the government in ICT fields [3]. While government policies are meant to help shape people's quality of life, they can also influence their lives [21]. E-government researches not merely only focus on the government as a service provider. The researches also focus on citizens as users of the system from the government [22]. Latest research about e-government done in Turkey. Indicated that its findings can guide professionals and policy makers to introduce e-government that prioritizes citizens as users. This is important to improve the government's reputation in providing public services [23]. Likewise, a research in Abu Dhabi (Emirates) incorporates two main dependent variables of UTAUT. The results obtained from this research UTAUT model can maximize its returns on ICT infrastructure investments aimed at providing efficient services to its citizens [24].

\subsection{Unified theory of acceptance and use of technology (UTAUT)}

Intention to use is a key factor in seeing the understanding of technology users [25]. Many models have been studied, researched and developed to explain the use of technology such as: theory of reasoned action model, theory of planned behavior model, technology acceptance model and unified theory of acceptance and use of technology [26].

Initially, the UTAUT model is a technology acceptance model that consists of a combination of eight technology acceptance models.: motivation model, theory of planned behavior, theory of reasoned action, technology acceptance model, combined TAM \& TPB, model of PC utilization (MPTU), innovation diffusion theory and social cognitive theory [26]. UTAUT model covering four main factors that contribute to intention to use performance expectancy, effort expectancy, social influence, and facilitation conditions are variable determinants the utaut model also identified four additional moderator variables, such as gender, experience, age, and voluntariness of use Figure 1 illustrates the UTAUT model.

UTAUT model is a popular theory used in measuring user intentions towards a technology. The development of this theory is proven by many studies in various fields [27]. UTAUT is the best in modelling that requires predictions for the future [28, 29]. Testing this theory is also often used and has explained that model is toughness and appropriate for reviewing the intentions of technology. The presence of research findings UTAUT model in e-government research produces many variations of new models that can be used as a reinforcement of the construct in seeing the intentions of users of information technology [30]. The development of the UTAUT model has focused on additional constructs aimed at the use of various technologies [31, 32].

In addition, to the main constructs of the UTAUT model enhanced by many researchers, moderators also became the focus of the research. Research findings related to the main moderators in UTAUT such as experience, age and the findings showed not influence on behavioral intentions of e-government users [24]. The main moderating effects of UTAUT could not be determined due to the non-homogenous data 
distribution of the data. Besides that, the de-mographics, namely, education level and internet experience of the people may differ from population average used [23].

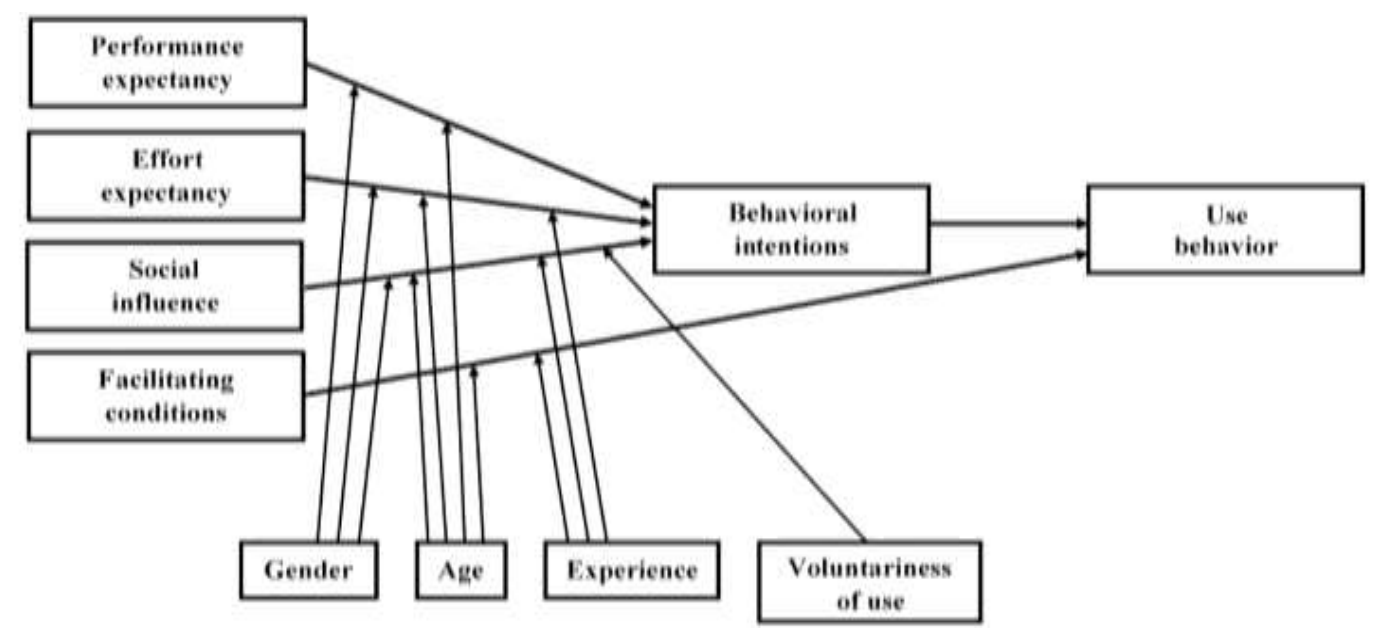

Figure 1. UTAUT model [26]

\subsubsection{Performance expectancy $(\mathrm{PE})$}

Performance expectancy is "as the degree to which an people believes that using the system will help to attain gains in performance" [26]. Interpreted to what extent the user gets a benefit for his work by using a system. Several studies relating to this theory have suggested that performance expectancy have a positive relationship with individual intention to use technology [33]. In research on technology adoption concluded that performance expectancy is an important variable in seeing the user behavior of technology.

\subsubsection{Effort expectancy (EE)}

Effort expectancy is "defined as the ease involved with the use of the system" [26]. Revealed that effort expectancy is important variable in seeing intentions to use technology [34]. The same findings revealed that effort expectancy has a significant relationship with intention to use technology [35]. A measure of a person's confidence in the system and believes that the results achieved will accelerate the user's goals.

\subsubsection{Social influence (SI)}

Social influence defined "as Individual perceives that important others believe he should use the system" [26]. Based on previous assumptions, social influence is also a strong variable in seeing intention to use technology [36]. Several studies have found that social influence has a significant relationship with individual attitudes in using technology.

\subsubsection{Facilitating conditions (FC)}

Facilitating conditions is defined "as the degree to which an individual believes that an organizational and technical infrastructure exists to support use of the system" [26]. Are a user's confidence in the means that support the use of a system [37]. Clearly, the new findings that facilitating conditions are important variables in seeing the intentions to use of technology. Reviewing the same research has also been carried out in various countries looking at intention to use. These studies are summarized in Table 1.

Table 1. Summary of studies on the intention to use e-government

\begin{tabular}{lccc}
\hline Years & Author & Research & Country \\
\hline 2015 & Daniel [38] & e-government services & Papua New Guinea \\
2016 & Bhuasiri et al [39] & e-tax Filing and Payment System & Thailand \\
2019 & Suki\&Suki [7] & Examining E-Voting & Malaysia \\
2019 & Mensah [40] & E-Government Services & China \\
2019 & Zolotov, Oliveira \& Casteleyn [4] & e-participation & Portugal \\
2019 & Mhina et al [33] & Web and Social Media & Tanzania \\
2019 & Alabboodi [6] & E-government services & Iraq \\
2020 & Sabani [41] & e-Government & Indonesia \\
\hline
\end{tabular}




\subsection{Attitude}

Initially, the attitude one of the theory of reasoned action model (TRA) constructs [42]. Attitude is a variable used in psychological studies [43]. Attitude is a determinant that is intended to restore consumer confidence in the use of their systems and passwords [44]. Attitude is an important construct and can contribute to e-government services [45]. Some studies make Attitude an important antecedent of intention to adopt technology [46]. Attitude is an important factor in adopting and using e-government [47]. Using a meta-analysis of 60 studies from over the last 17 years, the study concluded that attitude one of the 'best' and 'promising' predictors used to see the intention to use [48]. Clearly, the existing study indicated that the intent to use e-government is decided by the attitude.

Attitude was significant in increasing e-government user satisfaction and was also important and contributed to wider technology adoption. This does not only contribute to understanding how Attitude is a construct and also know that using technology is not only about related variables, but variations related to variables are also obtained. Additionally, study outside e-government, for example mobile learning using modified UTAUT and assessing. The size and trajectory of the effect of the UTAUT factor where they find Attitude is a major determinant of technology user behavior [49]. Use Attitude and major moderators such as education, age, experience, gender, individual impression, impact and organizational memory and conclude that there is a strong relationship in building UTAUT [50]. On the other hand, Attitude can be a mediator in the UTAUT model and has a direct influence on the intentions of e-government. Clearly, Attitude as a mediator, UTAUT has a significant effect on Attitude and has an effect on intention to use and Attitude is an important construct and can contribute to e-government services.

\section{PROPOSED FRAMEWORK}

Focal points research of intention to use electronic government is very important to be utilized. Discussion of electronic government is definitely connected to the growth of online government services for people [51]. Based on a literature, a research new model design is then developed that can be used to answer the research objectives. The basic model proposed is UTAUT model by Venkatesh et al., 2013.

The findings of e-government research have been conducted by the government in general, but not many have looked specifically at local governments in Indonesia. In fact, Indonesia is currently conducting public service reforms that began with improvements in the region. So, the authors suggest the purpose of future research plans looking at the relationship of construct factors in seeing the intention to use egovernment in local governments in Indonesia. Seeing the intention of users where the community as an object continues to be done.

Our assumption, by conducting research using this concept, will certainly obtain different results from the findings of various countries, especially developing countries. Entering Attitude as a moderator can certainly help the future development of the UTAUT model. The authors decided to integrate and develop the UTAUT model and use attitude as a mediator. Therefore, the proposed research model is explained as in the Figure 2.

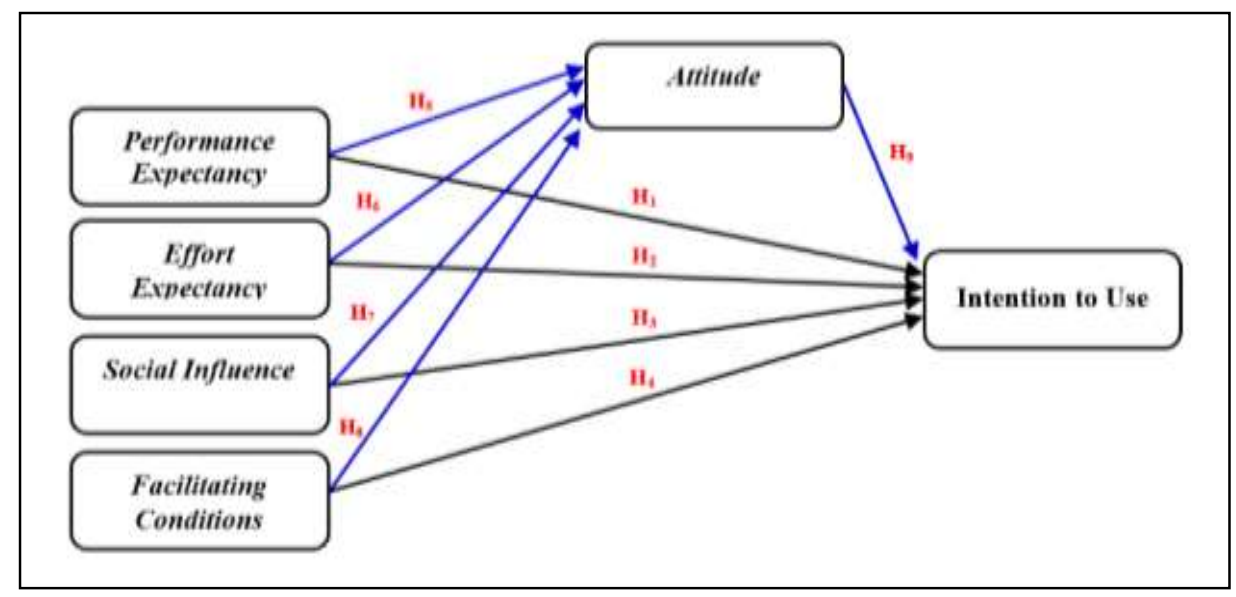

Figure 2. Conceptual framework 
Proposed hypothesis, 1) PE significantly and positively affects ITU, 2) EE significantly and positively affects ITU, 3) SI significantly and positively affects ITU, 4) FI significantly and positively affects ITU, 5) AT significantly mediates the relationship between PE and ITU, 6) AT significantly mediates the relationship between EE and ITU, 7) AT significantly mediates the relationship between SI and ITU, 8) AT significantly mediates the relationship between FC and ITU, and 9) AT significantly and positively affects ITU.

\section{CONCLUSION}

The results obtained from this research that the main construct of UTAUT such as performance expectancy (PE), effort expectancy (EE), social influence (SI), facilitating conditions (FC) is an important factor appropriate for seeing intention to citizen in using e-government. Besides that, UTAUT's moderators such as gender, age, experience, and voluntariness of use were excluded in the framework. Subsequently, the attitude constructs as a mediator in the purposed framework. On the whole, 9 hypotheses presented in the model that we propose are believed to get new findings in the future development of UTAUT model and be able to provide concept ideas that are made in seeing the intentions of e-government users. Our hope the framework will be a good input for the government to improve its electronic services and be able to provide input to be used as material for consideration for the Indonesian government in carrying out improvements to e-government services in Indonesia.

\section{ACKNOWLEDGEMENTS}

The authors wish to thank the School of Government, Universiti Utara Malaysia (UUM) for the resources and support.

\section{REFERENCES}

[1] T. Alam, A. A. Salem, A. O. Alsharif, and A. M. Alhejaili, "Smart home automation towards the development of smart cities," Comput. Sci. Inf. Technol., vol. 1, no. 1, pp. 17-25, 2020, doi: 10.11591/csit.v1i1.p17-25.

[2] P. O. Sadiku, R. O. Ogundokun, O. E. Ogundokun, and A. A. Adebayo, "Interactive website on information dissemination," Telkomnika (Telecommunication Comput. Electron. Control., vol. 19, no. 1, pp. 115-123, 2020, doi: 10.12928/TELKOMNIKA.V19I1.15048.

[3] A. H. Katrawi, R. Abdullah, M. Anbar, I. AlShourbaji, and A. K. Abasi, "Straggler handling approaches in mapreduce framework: A comparative study," Int. J. Electr. Comput. Eng., vol. 11, no. 1, pp. 375-382, 2021, doi: 10.11591/ijece.v11i1.pp375-382.

[4] M. Naranjo Zolotov, T. Oliveira, and S. Casteleyn, "Citizens' intention to use and recommend e-participation: Drawing upon UTAUT and citizen empowerment," Inf. Technol. People, vol. 32, no. 2, pp. 364-386, 2019.

[5] I. K. Mensah and S. Adams, "A comparative analysis of the impact of political trust on the adoption of egovernment services," Int. J. Public Adm., vol. 42, no. 2, pp. 1-15, 2019, doi: 10.1080/01900692.2019.1645687.

[6] Alabboodi, A. S. Shaban, and N. Saleh, "The adoption of e-government services in the Iraqi higher education context: An application of the UTAUT model in the university of Baghdad," Int. J. Appl. Res., vol. 5, no. 5, pp. 130-137, 2019.

[7] N. M. Suki and N. Suki, "Examining e-voting intention in an emerging nation: towards a unified view," Malaysian Journal of Consumer and Family Economics, pp. 110-124, 2019.

[8] I. Farida, R. Setiawan, A. S. Maryatmi, and M. N. Juwita, "The implementation of e goverment in the industrial revolution era 40 in indoneasia," Int. J. Progress. Sci. Technol., vol. 22, no. 2, pp. 340-3, 2021.

[9] A. Lase and B. Ranti, "Developing the indonesian government enterprise architecture framework appropriate for Indonesian government agencies," Int. J. Informatics Commun. Technol., vol. 8, no. 3, p. 152, 2019, doi: 10.11591/ijict.v8i3.pp152-161.

[10] B. Hermana and W. Silfianti, "Evaluating e-government implementation by local government: digital divide in internet based public services in Indonesia," Int. J. Bus. Soc., vol. 2, no. 3, pp. 156-164, 2011.

[11] D. Napitupulu and S. Syafrullah2, Rahim, Amar, "Content validity of critical success factors for e- Government implementation in Indonesia content validity of critical success factors for e-government implementation in Indonesia," IOP Conference Series: Materials Science and Engineering, vol. 352, The 7th AIC-ICMR on Sciences and Engineering 2017, 18-20 October 2017, Banda Aceh, Indonesia, doi: 10.1088/1757-899X/352/1/012058.

[12] D. Afrizal, "E- government service review in Dumai City Indonesia : (conceptual paper)," J. Niara, vol. 13, no. 1, pp. 260-267, 2020.

[13] UN, "UN e-government surveys," Department of Economic and Social Affairs Public Institutions, United Nations, 2018. https://publicadministration.un.org/en/Research/UN-e-Government-Surveys (accessed Dec. 12, 2019).

[14] A. Sabani, H. Deng, and Thai Vinh, "Evaluating the development of e-government in Indonesia," in In Proceedings of the 2nd International Conference on Software Engineering and Information Management, 2019, pp. 254-258.

[15] D. Napitupulu, "Kajian faktor sukses implementasi e-government," J. Sist. Inf., vol. 5, no. 3, pp. 229-236, 2015, doi: 10.24089/j.sisfo.2015.03.009. 
[16] D. Napitupulu, "Empirical study of critical success factors for e-government implementation in Indonesia based on factor analysis approach," J. Bina Praja, vol. 9, no. 1, pp. 83-99, 2017, doi: 10.21787/jbp.09.2017.83-99.

[17] A. Garad and I. N. Qamari, "Determining factors influencing establishing e-service quality in developing countries," Int. J. Electron. Gov. Res., vol. 17, no. 1, pp. 15-30, 2021, doi: 10.4018/ijegr.2021010102.

[18] W. Muslimin, "Determinants that Influence citizen's usage of different e-government services: a Malaysian case study," thesis, The University of Queensland, Australia 2018.

[19] K. A. Mutaqin and E. Sutoyo, "Analysis of citizens acceptance for e-government services in Bandung, Indonesia: the use of the unified theory of acceptance and use of technology (UTAUT) model," Bull. Comput. Sci. Electr. Eng., vol. 1, no. 1, pp. 19-25, 2020, doi: 10.25008/bcsee.v1i1.3.

[20] United Nations News Centre, "E -government a powerful tool to implement global sustainability goals, UN survey finds," 2016. www.un.org/apps/news/story.asp? NewsID=54617\#.WkK5KIT1WRs (accessed Sep. 21, 2019).

[21] H. Iqbal, S. Paul, and K. Khan, "Sustainable governance in smart cities and use of supervised learning based opinion mining," Int. J. Electr. Comput. Eng., vol. 11, no. 1, pp. 489-497, 2021, doi: 10.11591/ijece.v11i1.pp498497.

[22] M. A. Alryalat, \& A., Rana, N. P., and Y. K. Dwivedi, "Citizen's adoption of an e-government system: validating the extended theory of reasoned action (TRA)," Open Gov. Concepts, Methodol. Tools, Appl., pp. 651-674, 2020.

[23] M. Kurfal1, A. Arifoğlu, G. Tokdemir, and Y. Paçin, "Adoption of e-government services in Turkey," Comput. Human Behav., vol. 66, pp. 168-178, 2017, doi: 10.1016/j.chb.2016.09.041.

[24] K. A. A. Mansoori, J. Sarabdeen, and A. L. Tchantchane, "Investigating emirati citizens adoption of e-government services in Abu Dhabi using modified UTAUT model," Inf. Technol. People, vol. 31, no. 2, pp. 455-481, 2018.

[25] Y. K. Dwivedi, N. P. Rana, K. Tamilmani, and R. Raman, "A meta-analysis based modified unified theory of acceptance and use of technology (meta-UTAUT): a review of emerging literature," Curr. Opin. Psychol., vol. 36, pp. 13-18, 2020, doi: 10.1016/j.copsyc.2020.03.008.

[26] V. Venkatesh, M. G. Morris, G. B. Davis, and F. D. Davis, "User acceptance of information technology: toward a unified view," MIS Q., vol. 27, no. 3, pp. 425-478, 2003.

[27] P. J. Venkatesh, V., Thong, J. Y., Chan, F. K., and Hu, "Managing citizens' uncertainty in e-government services: The mediating and moderating roles of transparency and trust," Inf. Syst. Res., vol. 27, no. 1, pp. 87-111, 2016.

[28] A. Tarhini, A., El-Masri, M., Ali, M., \& Serrano, "Extending the UTAUT model to understand the customers' acceptance and use of internet banking in Lebanon: A structural equation modeling approach," Inf. Technol. People, vol. 29, no. 4, pp. 830-849, 2016, doi: 10.1108/ITP-02-2014-0034.

[29] K. Ahmed et al., "Information Technology \& People Article information," 2018.

[30] N. C. Nawi, A. A. Mamun, N. A. M. Nasir, and R. Muniady, "Factors affecting the adoption of social media as a business platform : a study among student entrepreneurs in Malaysia," Vision, vol. 23, no. 1, pp. 1-11, 2019.

[31] V. Venkatesh, "Adoption and use of AI tools: a research agenda grounded in UTAUT," Ann. Oper. Res., 2021, doi: 10.1007/s10479-020-03918-9.

[32] D. Napitupulu, P. D. Ananto Pamungkas, B. G. Sudarsono, S. P. Lestari, and A. U. Bani, "Proposed TRUTAUT model of technology ddoption for LAPOR!," IOP Conf. Ser. Mater. Sci. Eng., vol. 725, no. 1, 2020, doi: 10.1088/1757-899X/725/1/012120.

[33] J. R. A. Mhina, M. G. Md Johar, and M. H. Alkawaz, "The influence of perceived confidentiality risks and attitude on tanzania government employees' intention to adopt web 2. 0 and social media for work-related purposes the influence of perceived confidentiality risks and attitude on Tanzania," Int. J. Public Adm., vol. 42, no. 7, pp. 558571, 2018, doi: 10.1080/01900692.2018.1491596.

[34] H. Khechine, S. Lakhal, and P. Ndjambou, "A meta-analysis of the UTAUT model: Eleven years later," Can. J. Adm. Sci. Can. des Sci. l'Administration, vol. 33, no. 2, pp. 138-152, 2016.

[35] A. Mosunmola, A. Mayowa, S. Okuboyejo, and C. Adeniji, "Adoption and use of mobile learning in higher education: the UTAUT model," in International Conference on E-Education, E-Business, E-Management and ELearning, 2018, pp. 20-25.

[36] H. Khechine and M. Augier, "Adoption of a Social learning platform in higher education : an extended UTAUT model implementation," in Hawaii International Conference on System Sciences., 2019, pp. 53-62.

[37] Jia Jia Sim, Zui Ying Chia, Yhuen Loong Chin, Mei Qi Lee, Vernon Tat Seng Chiam, Kee Luen Wong, et al., "Trust in vendor and perceived effectiveness of e-commerce institutional mechanisms in m-commerce adoption: a revised UTAUT model," in International Conference on Control System, Computing and Engineering (ICCSCE), 2018, pp. 10-15, doi: 10.1109/ICCSCE.2018.8684964.

[38] M. Daniel, "Electronic government: Understanding factors affecting citizen adoption in Papua New Guinea using the UTAUT," DWU Res. J., vol. 23, February, pp. 1-12, 2015.

[39] [W. Bhuasiri, H. Zo, H. Lee, and A. P. Ciganek, "User acceptance of e-government services: examining an e-tax filing and payment system in Thailand," Inf. Technol. Dev., vol. 22, no. 4, pp. 672-695, 2016.

[40] I. K. Mensah, "Factors Influencing the intention of university students to adopt and use e-government services : an empirical evidence in China," Sage OpenOpen, vol. 9, no. 2, 2019.

[41] A. Sabani, "Investigating the influence of transparency on the adoption of e-Government in Indonesia," J. Sci. Technol. Policy Manag., 2020, doi: 10.1108/JSTPM-03-2020-0046.

[42] I. Ajzen and M. Fishbein, "Attitude-behavior relations : a theoretical analysis and review of empirical research," vol. 84, no. 5, pp. 888-918, 1977.

[43] M. Ajzen, I \& Fishbein, "Theory of Reasoned Action (TRA)," 1980.

[44] S. Osswald, D. Wurhofer, S. Trösterer, E. Beck, and M. Tscheligi, "Predicting information technology usage in the 
car : towards a car technology acceptance model," Proceedings of the 4th International Conference on Automotive User Interfaces and Interactive Vehicular Applications, October 2012, pp. 51-58 doi: 10.1145/2390256.2390264.

[45] S. Rodrigues, G., Sarabdeen, J., and Balasubramanian, "Factors that influence consumer adoption of e-government services in the UAE: A UTAUT model perspective," J. Internet Commer., vol. 15, no. 1, pp. 18-39, 2016, doi: 10.1080/15332861.2015.1121460.

[46] M. Janssen, N. P. Rana, E. L. Slade, and Y. Dwivedi, "Trustworthiness of digital government services : deriving a comprehensive theory through interpretive structural modelling," Public Manag. Rev., vol. 20, no. 05, pp. 647-671, 2017, doi: 10.1080/14719037.2017.1305689.

[47] H. Zahid and B. H. Din, "Determinants of intention to adopt e-government services in Pakistan : an imperative for," Resources, vol. 8, no. 3, p. 128, 2019.

[48] M. N. Zolotov, T. Oliveira, and S. Casteleyn, "E-participation adoption models research in the last 17 years: A weight and meta-analytical review," Comput. Human Behav., vol. 81, pp. 350-365, 2018.

[49] T. Thomas, L. Singh, and K. Gaffar, "The utility of the UTAUT model in explaining mobile learning adoption in higher education in Guyana," Int. J. Educ. Dev. using ICT, vol. 9, no. 3, pp. 71-85, 2013.

[50] A. K. Sharma, "User acceptance of desktop based computer software using UTAUT model and addition of new moderators," vol. 3, no. 10, pp. 509-515, 2012.

[51] K. P. Gupta, S. Singh, and P. Bhaskar, "Citizen adoption of e-government: A literature review and conceptual framework," Electronic Government an International Journal, vol. 12, no. 2, p. 160, 2016, doi: 10.1504/EG.2016.076134.

\section{BIOGRAPHIES OF AUTHORS}

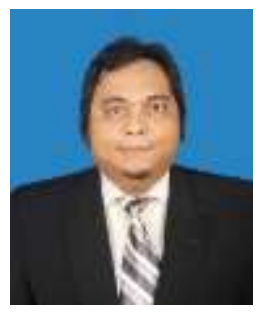

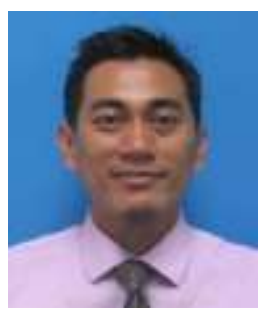

Dedy Afrizal is a lecturer in Management Program, STIE Tuah Negeri Dumai, Riau, Indonesia. Received the Master degrees from Universiti of Riau Indonesia, 2013. Moreover, he is Ph.D. candidate at Universiti Utara Malaysia. His current research interest includes E-Government, eService, Technology Adoption in the public sector. Since 2017, he has been the head of the research \& development institute on campus and has collaborated with public agencies and semigovernment companies in conducting academic studies. He was engaged in research and development of the public sector from 2015 to 2020 in Indonesia.

Dr. Muslimin Walang is a Senior Lecturer in Universiti Utara Malaysia. Is holds Bachelor Degree (2001) Public Management in Universiti Utara Malaysia, (2003) Master of Science Public Service Management, University of Birmingham, United Kingdom, and (2018) Ph.D. e-government, University of Queensland, Australia. His research is focused on e-government ICT in public sector, local authority and digital, information technology and politics, communication and media, quantitative social research, public administration. 